\title{
Effect of Zirconium Chloride as a Mordant on Flammability of Dyeing Wool with Madder
}

\author{
ARASH ALMASIAN ${ }^{1}$, LALEH MALEKNIA ${ }^{2 *}$ and ABOSAID RASHIDI ${ }^{3}$ \\ 'Department of Textile Engineering- Islamic Azad University-South Tehran Branch, Iran. \\ ${ }^{2}$ Department of Textile Engineering- Islamic Azad University-South Tehran Branch, Iran. \\ ${ }^{3}$ Department of Textile Engineering- Islamic Azad University, \\ Science and Research Branch, Tehran, Iran. \\ *Corresponding author E-mail: arashalmasi@yahoo.com \\ http://dx.doi.org/10.13005/ojc/310106
}

(Received: December 06, 2014; Accepted: January 12, 2015)

\begin{abstract}
In this research, the effect of zirconium salt as a mordant on flammabilityof dyeingwool fabric with madder was studied. Wool fabrics were treated with different concentrations of zirconium salt in water solution including 1, 3, 6 and 9\% o.w.f. and the dyeing process was carried out on the fabrics in the states before, simultaneously and after-mordanting with madder. Formic acid and oxalic acid were used to generate acidic $\mathrm{pH}$.The chemical characteristics and the changes induced by zirconium were investigated by Fourier-transform infrared spectra (FTIR). Flammability of samples was investigated by horizontal flammability test (HFT). The surfaces of untreated and treated fabrics were evaluated by scanning electron microscopy to observe the morphological changes. The EDX results showed presence of zirconium salt on the surface of wool. The results show that zirconium treated fabrics have a higher weight and lower bending rigidity compared to untreated ones. Furthermore,the zirconium mordant made the wool fabric hydrophobic.
\end{abstract}

Key words:wool fabric, zirconium, madder, flammability.

\section{INTRODUCTION}

The wool is a natural fiber with the protein structure ${ }^{1}$. We can note to properties of high water absorption (18 percent), reversible capacity due to $\alpha$-helix structure, and high resistance to fire ${ }^{2}$.

Natural dyes or colorants derived from flora and fauna are believed to be safe because of their non-toxic, non-carcinogenic and biodegradable nature. The present trend throughout the world is shifting towards the use of ecofriendly and biodegradable commodities. This leads to increasing demand for natural dyes ${ }^{3}$. Madder is widely distributed in southern and southeastern Europe, the Mediterranean area and in Asia. It is a main source of natural dye producing a variety of anthraquinone pigments in its roots and rhizomes. The main components are di- and tri-hydroxyanthraquinones, alizarin and purpurin and their 
derivatives, ruberythricacid(alizarin-primeveroside), pseudopurpurin and lucidin-primeveroside. Rubiadin, munjistin, quinizarin (1,4 di-hydroxyanthraquinone), lucidin, nordamnacanthal, xanthopurpurin and 1,8-di-hydroxy-anthraquinone are also identified from plant tissues ${ }^{4-6}$. Madder is an old and famous dye for dyeing wool, silk and cotton fibers ${ }^{6}$. Banyai et al., ${ }^{4}$ determined the amount of alizarin and purpurin in madder. They also reported that quinizarin and 1,8dihydroxyanthraquinone were not observed in their samples ${ }^{4}$. The chemical structure of more important coloring compounds, i.e. alizarin and purpurin are presented in Figure 1.

Natural dye madder is not able to create a strong bond with the wool fiber. Therefore, it should be used asa substance forhelping create a strong bond between dye and fiber. Mordant is the substance of helping, which the two reasons are important: 1 . creates a link with the dye and affect on the color fastness, however, the mordant should be optimized; 2 . the mordant effect on the shade therefore wide range of mordant can be achieved wide shads.

Nearly all previous research is focused on the enzyme treated and inorganic mordants (AL, $\mathrm{Cu}, \mathrm{Zn}, \mathrm{Ne} . .$. ) on the wool. However, as far as we know, none of the recent research studies has focused on stabilization of $\mathrm{ZrCl}_{4}$ on wool using oxalic acid and formic acid. Attempts were made in the present study to investigate different physical and chemical properties of oxalic or formic acid/ zirconiumsalt coated wool fiber.

\section{EXPERIMENTS}

\section{Materials and Methods}

The wool fabric with the weight $1688.55 \mathrm{~g} /$ $\mathrm{m}^{2}$, width $140 \mathrm{~cm}$ was used from Iran Merinos Co. The anionic detergent was used for scouring the wool. The mordant used was zirconium chloride (IV) $\left(\mathrm{ZrCl}_{4}\right)$. It was produced by Merck. Also, Formic acid and oxalic acid from Merck was applied for dyeing process. Powder of Iranian madder roots was used for dyeing of wool fabrics.

The mordanting treatments were carried out before, simultaneously and after the dyeing.
Zirconium salt concentrations of $\% 1, \% 3, \% 6$ and 9\% o.w.f. were used and the liquor ratio was 50:1. Following the mordanting treatment, the fabrics were maintained for $1 \mathrm{~h}$ at a temperature of $85^{\circ} \mathrm{C}$. Dye solutions were prepared $24 h$ prior to dyeing by adding madder powder to water ( $50 \%$ o.w.f., liquor ratio 50:1). The dyeing process was started at $40^{\circ} \mathrm{C}$ and the temperature was increased to $85^{\circ} \mathrm{C}$ over $20 \mathrm{~min}$ and then held at that temperature for $1 h$; finally, the fabrics were rinsed. The acidic $\mathrm{pH}$ was maintained using formic acid and oxalic acid.

\section{Analytical Methods}

Fourier-Transform Infrared Spectroscopy (FTIR)

The chemical compositions of the fabrics were examined by the FTIR spectroscopy [BomemMB 100 Series (Hartmann and Broun)rsqb].

\section{Determination of Flammability}

Flammability of samples was evaluated in accordance with ASTM D 635. Five samples from each fabric were cut with dimensions of $10 \times 2 \mathrm{~cm}$. Specimens were placed in the flammability chamber in the horizontal position (Figure 2). After testing, the time and extent of burning area were measured and the rate of burning (V) was calculated in millimeters per second $(\mathrm{mm} / \mathrm{s})$ for each specimen by the following formula:

$$
\mathrm{V}=\mathrm{L} / \mathrm{T}
$$

where $L$ is the burned length in millimeters $(\mathrm{mm})$ and $\mathrm{T}$ is the time in seconds $(\mathrm{s})^{7,8}$.

\section{Microscopic Characterization}

The surface of the fibers was investigated using a Scanning Electron Microscope (SEM XL30, Philips). The surface of samples was first coated with a thin layer of gold (w10 $\mathrm{nm}$ ) by Physical Vapor Deposition method (PVD) using a sputter coater (SCDOOS, BAL-TEC). The presence of zirconia on fiber surface was also determined by energy dispersive X-ray microanalysis (EDX) attached to the SEM.

\section{The Vertical Drop Test}

The vertical drop test wascarried out on fabrics with BS 4554. A drop of distilled water was placed onto the fabric sample and the time by which the liquid required to sink completelyinto the fabric 
was recorded. The shorter the time, the more wettablewas the fabric.

\section{Determination of Weight Increment}

All samples were conditioned in oven at $60 \pm 2^{\circ} \mathrm{C}$ for $30 \mathrm{~min}$ then were put indesiccators for $15 \mathrm{~min}$ and were weighed before and after treatment. The weight increase of each sample (WI\%) was calculated as:

$$
\mathrm{WI} \%=\frac{\left(W_{2}-W_{1}\right)}{W_{2}} \times 100
$$

Where $W_{1}$ is the conditioned weight of sample before treatment and $\mathrm{W}_{2}$ is theconditioned weight of sample after treatment.

\section{Evaluation of Bending Rigidity}

In this test, a rectangular strip of fabric is supported on a horizontal platform in a direction perpendicular to one edge of the platform (BS 3356). The strip is extended in the direction of its length so that an increasing part overhangs and bends don under its own mass. When the tip of the specimen has reached a plane passing through the edge of the platform and inclined at an angle of $41.5^{\circ}$ below the horizontal, the overhanging length is equal to twice the bending length of the specimen. The flexural rigidity $(G)$ is obtained from the bending length $(C)$ and the mass per unit area of the fabric (M).

$$
G=M * C^{3} * 0.1
$$

\section{Color coordinates}

CIELAB color coordinates $\left(L^{*}, a^{*}, b^{*}, C^{*}\right.$ and $h$ ) were calculated for control and treatment samples at $10^{\circ}$ observer and illuminant $D_{65}$.

\section{RESULTSAND DISCUSSION}

\section{Structural Information by FTIR Spectra}

The infrared spectra of untreated wool as well as the sample mordanted with zirconium saltare shown in Figures3 and4. The $\mathrm{N}-\mathrm{H}$ stretching and bending vibrations in wool are usually appeared at $3100-3500 \mathrm{~cm}^{-1}$ and $1550-1640 \mathrm{~cm}^{-1}$ respectively, depending on the type of amide (primary and secondary), chemical environment (solid and liquid) and intra- or inter-molecular hydrogen bonds. The $\mathrm{C}=\mathrm{O}$ stretching vibration band appears in the normal region between 1630 and $1670 \mathrm{~cm}^{-1}$ which usually overlaps with $\mathrm{N}-\mathrm{H}$ bending ${ }^{9,10}$.

Figures3a and $4 \mathrm{a}$ presentN-H stretching of a secondary amide at $3251 \mathrm{~cm}^{-1}$ as expected for wool. The bands at $1634 \mathrm{~cm}^{-1}$ are also characteristic of $\mathrm{N}-\mathrm{H}$ stretching vibration which overlaps with $\mathrm{C}=\mathrm{O}$ vibration. The weak $\mathrm{C}-\mathrm{H}$ stretching, $\mathrm{CH}_{2}$ out of plane bending, C-O-C asymmetric stretching and S-O-S (cystine monoxide) vibrations in wool appear at 2919, 835, 1232 and $1072 \mathrm{~cm}^{-1}$, respectively. Other weak bands appeared at 3759 and $3682 \mathrm{~cm}^{-1}$ are attributable to $\mathrm{O}-\mathrm{H}$ stretching vibrations in free primary and secondary alcohols ${ }^{10}$.

Figure $3 b$ shows oxalic acid treated wool / $9 \%$ zirconium salt, the new bands at 3852 and $3811 \mathrm{~cm}^{-1}$ were appeared. These changes are due to generation of free alcohols on one hand and increase of $\mathrm{OH}$ groups on the other hand forming hydrogen linkages, after $\mathrm{H}_{2} \mathrm{O}$ entry. Other changes are intensity increments of 2924, 1654 and $1701 \mathrm{~cm}$ ${ }^{1}$ due to conformation change of $\mathrm{CH}$ stretching and bending in presence of oxalic acid, and interaction

Table 1: Burning rate for a) untreated wool b)mordantedwith $9 \%$ zirconium saltwool

\begin{tabular}{|c|c|c|c|c|c|c|}
\hline \multirow[t]{2}{*}{ Sample } & \multicolumn{3}{|c|}{ Oxalic acid } & \multicolumn{3}{|c|}{ Formic acid } \\
\hline & $\begin{array}{c}\text { Burned } \\
\text { length }(\mathrm{mm})\end{array}$ & $\begin{array}{l}\text { Ignition } \\
\text { time (s) }\end{array}$ & $\begin{array}{c}\text { Burning } \\
\text { rate }(\mathrm{mm} / \mathrm{s})\end{array}$ & $\begin{array}{c}\text { Burned } \\
\text { length }(\mathrm{mm})\end{array}$ & $\begin{array}{l}\text { Ignition } \\
\text { time (s) }\end{array}$ & $\begin{array}{c}\text { Burning } \\
\text { rate }(\mathrm{mm} / \mathrm{s})\end{array}$ \\
\hline$A$ & 80 & 2.71 & 29.52 & 80 & 2.71 & 29.52 \\
\hline B & 31 & 4.27 & 7.25 & 15 & 4.99 & 31 \\
\hline $\mathrm{C}$ & 67 & 7 & 16.75 & 65 & 4.05 & 16.04 \\
\hline $\mathrm{D}$ & 23 & 4.82 & 4.77 & 28 & 4.58 & 6.11 \\
\hline
\end{tabular}
c)dyeing with madderwool d)dyeing with madder and $9 \%$ zirconium saltwool 
between carboxylic anions of wool and acid cations, respectively. The band at $1391 \mathrm{~cm}^{-1}$ was disappeared due to change in $\mathrm{CH}$ stretching and bending vibrations after beingmordanted. The intensity of the bands at 1066 and $533 \mathrm{~cm}^{-1}$ were increased, that are due to intebeiraction between oxalic acid anions and amino groups of wool and change of OCN conformation in amide groups after-mordanted, respectively. Figure $4 \mathrm{~b}$ indicatesformic acid treated wool / $9 \%$ zirconium salt, the intensity of bands at

Table 2: Energy dispersive X-ray analysis inboth formic and oxalic acid environments(a) dyeing with madder wool fiber, (b) wool fibers dyeing with madder and $1 \%$ zirconium salt in before- mordantmethod (c) wool fibers dyeing with madder and 9\%zirconium salt in before- mordantmethod (d) wool fibers dyeing with madder and $1 \%$ zirconium salt in simultaneously-mordant method (e) wool fibers dyeing with madder and 9\%zirconium saltinsimultaneously-mordant method (f) wool fibers dyeing with madder and $1 \%$ zirconium salt in after- mordantmethod $(\mathrm{g})$ wool fibers dyeing with madder and $9 \%$ zirconium salt in after- mordantmethod

\begin{tabular}{lccccc}
\hline \multirow{2}{*}{$\begin{array}{l}\text { Method } \\
\text { Quantity of zirconium } \\
\text { salt (O.W.F\%) }\end{array}$} & \multicolumn{4}{c}{ Oxalic acid Formic acid } \\
\cline { 3 - 6 } & & $\operatorname{Zr}(\%)$ & $\operatorname{Au}(\%)$ & $\operatorname{Zr}(\%)$ & $\operatorname{Au}(\%)$ \\
\hline \multirow{2}{*}{ before mordant } & 1 & 6.31 & 93.69 & 8.34 & 91.66 \\
\multirow{2}{*}{ simultaneously mordant } & 9 & 8.7 & 91.3 & 10.03 & 89.97 \\
\multirow{2}{*}{ after-mordant } & 9 & 6.97 & 93.03 & 8.09 & 91.91 \\
& 1 & 8.06 & 91.94 & 10.33 & 89.67 \\
& 9 & 8.15 & 91.85 & 10.34 & 89.66 \\
\hline
\end{tabular}

Table 3: Color co-ordinates of unmordanted and zirconium salt mordanted madder dyedwool in Oxalic acid (standard deviations in parentheses)

\begin{tabular}{|c|c|c|c|c|c|c|c|c|c|c|c|c|c|}
\hline & \multicolumn{4}{|c|}{ Before-mordant } & \multicolumn{5}{|c|}{ Simultaneously-mordant } & \multicolumn{4}{|c|}{ After-mordant } \\
\hline & $0 \%$ & $1 \%$ & $3 \%$ & $6 \%$ & $9 \%$ & $1 \%$ & $3 \%$ & $6 \%$ & $9 \%$ & $1 \%$ & $3 \%$ & $6 \%$ & $9 \%$ \\
\hline $\mathrm{L}^{*}$ & 58.5 & 60.0 & 56.8 & 53.8 & 53.4 & 57.8 & 57.4 & 56.9 & 54.7 & 59.4 & 60.0 & 59.7 & 59.6 \\
\hline$a^{*}$ & 22.6 & 26.6 & 22.3 & 21.6 & 21.3 & 20.5 & 19.7 & 20.4 & 20.5 & 22.6 & 20.9 & 19.8 & 19.7 \\
\hline$b^{*}$ & 29.8 & 33.4 & 25.4 & 17.2 & 15.8 & 27.7 & 26.9 & 25.8 & 19.9 & 31.7 & 33.5 & 32.8 & 32.5 \\
\hline$c$ & 37.4 & 40.3 & 33.8 & 27.6 & 26.5 & 34.5 & 33.3 & 32.9 & 28.5 & 39.0 & 39.5 & 38.3 & 38.0 \\
\hline $\mathrm{h}$ & 52.8 & 55.9 & 48.7 & 38.6 & 3605 & 53.5 & 53.8 & 51.7 & 44.2 & 54.5 & 58.1 & 58.9 & 58.8 \\
\hline
\end{tabular}

Table 4: Color co-ordinates of unmordanted and zirconium salt mordanted madder dyedwool in Formic acid (standard deviations in parentheses)

\begin{tabular}{|c|c|c|c|c|c|c|c|c|c|c|c|c|c|}
\hline & \multicolumn{4}{|c|}{ Before-mordant } & \multicolumn{5}{|c|}{ Simultaneously-mordant } & \multicolumn{4}{|c|}{ After-mordant } \\
\hline & $0 \%$ & $1 \%$ & $3 \%$ & $6 \%$ & $9 \%$ & $1 \%$ & $3 \%$ & $6 \%$ & $9 \%$ & $1 \%$ & $3 \%$ & $6 \%$ & $9 \%$ \\
\hline$L^{*}$ & 59.9 & 61.3 & 65.0 & 65.5 & 65.8 & 59.9 & 60.4 & 61.8 & 58.0 & 59.7 & 59.2 & 58.9 & 61.5 \\
\hline$a^{*}$ & 19.9 & 22.8 & 15.6 & 17.6 & 21.5 & 18.3 & 24.6 & 22.1 & 16.1 & 21.2 & 17.9 & 17.1 & 25.1 \\
\hline$b^{*}$ & 24.2 & 27.7 & 25.7 & 37.0 & 37.9 & 23.5 & 25.2 & 28.9 & 18.9 & 23.3 & 22.1 & 21.3 & 27.9 \\
\hline C & 31.3 & 35.8 & 38.9 & 40.9 & 43.5 & 29.7 & 35.3 & 36.4 & 24.8 & 31.6 & 28.5 & 27.3 & 37.6 \\
\hline $\mathrm{h}$ & 50.5 & 50.5 & 66.3 & 64.5 & 60.4 & 52.1 & 45.6 & 52.6 & 49.6 & 47.7 & 51.1 & 51.3 & 48.0 \\
\hline
\end{tabular}


<smiles>O=C1c2ccccc2C(=O)c2c1ccc(O)c2O</smiles>

Nizarin<smiles>O=C1c2ccccc2C(=O)c2c(O)ccc(O)c21</smiles>

1,4-dihydroxyanthraquinona

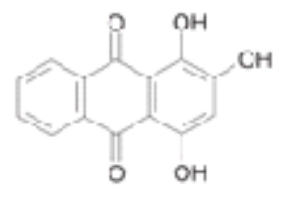

Purpurin

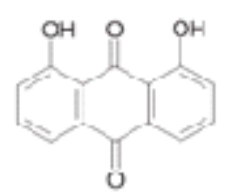

18-dihydroxyarth'aquinone

Fig. 1: Chemical structure of the main compounds ofMadder[3]

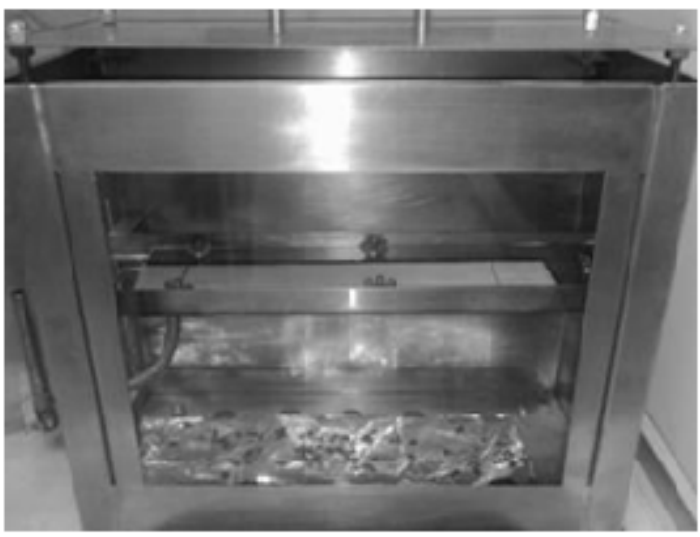

Fig. 2: Flame chamber used in this study with horizontal position for samples

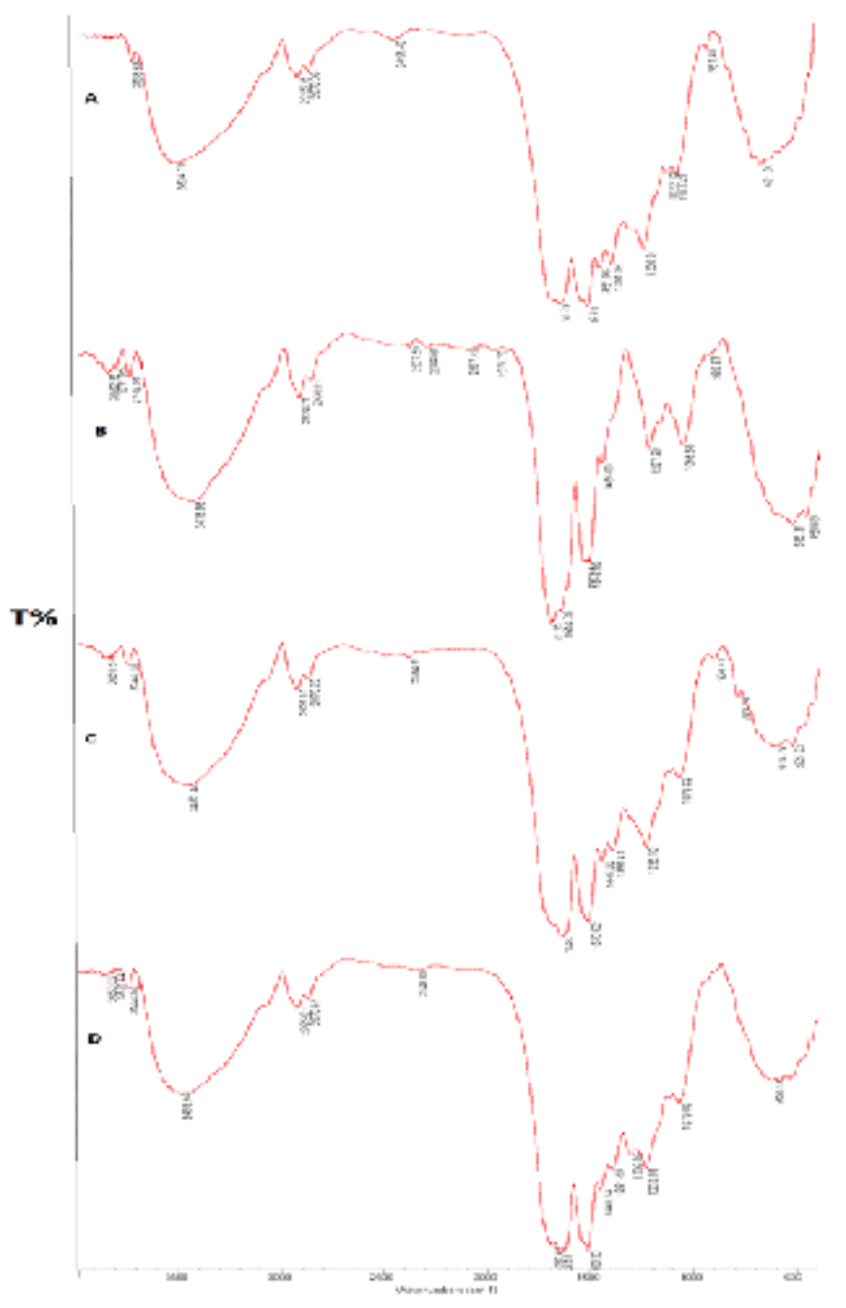

Fig. 3: FTIR spectra a) untreated wool, b) 9\% zirconium salt treated wool in oxalic acid, c) madder dyeing wool in oxalic acid, d) $9 \%$ zirconium salt / madder wool in oxalic acid 
3811 and $3852 \mathrm{~cm}^{-1}$ were increased and new band at $1701 \mathrm{~cm}^{-1}$ was appeared. These changes are due to interaction $\mathrm{OH}$ groups of wool and interaction between carboxylic wool and Formic acid cations. The band at $1391 \mathrm{~cm}^{-b y 1}$ was disappeared due to $\mathrm{CH}$ stretching and bending vibration after-mordant ed. The intensity of the bands at 1065 and $502 \mathrm{~cm}^{-}$
${ }^{1}$ were increased, that are due to interaction between Formic acid anions and amino groups of wool and change of OCN conformation in amide groups, respectively.

As can be seen in Figures $3 c$ and $4 c$, dyeing wool structure was thesame as untreated wool. The

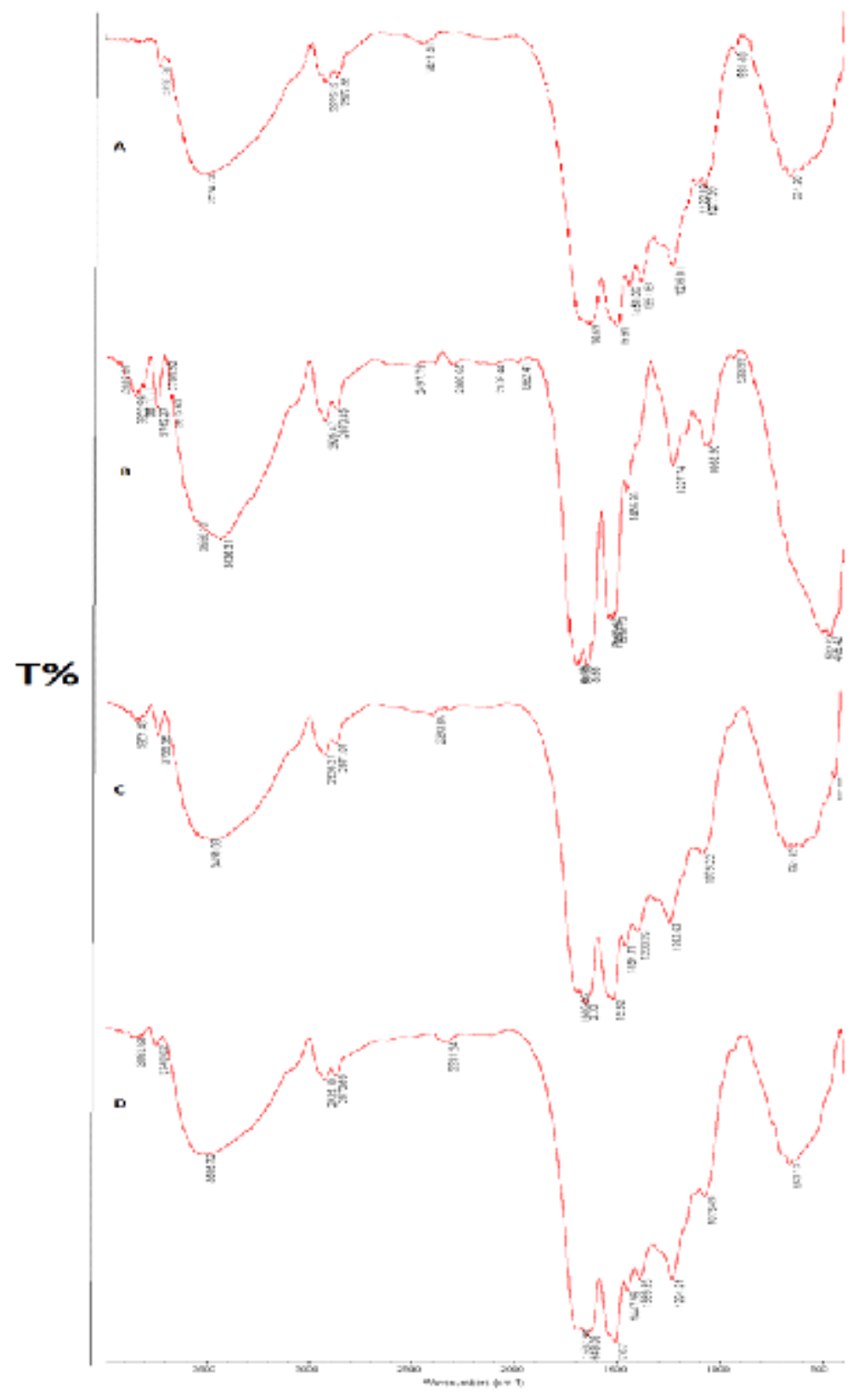

Fig. 4: FTIR spectra a) untreated wool, b) 9\% zirconium salt treated wool in formic acid, c) madder dyeing wool in formic acid, d) $9 \%$ zirconium salt / madder wool in formic acid 
intensity of the band at $3853 \mathrm{~cm}^{-1}$ was increased and new band at $793 \mathrm{~cm}^{-1}$ was appeared in oxalic acid. These changes are due to interaction between $\mathrm{OH}$ dye and amide band of wool. The intensity of band at $3851 \mathrm{~cm}^{-1}$ was increased. Its change is due to dye absorbent and increment of $\mathrm{OH}$ bands of anthraquinone in wool.

As can be seen inFigure $3 d$, in $9 \%$ zirconium / madder wool sample, the band at 1391 $\mathrm{cm}^{-1}$ was decreased as compared with untreated wool. This could be due to change of $\mathrm{CH}$ stretching and bending vibrations and also in Figure $4 d$, decrement in the intensity of band at $3516 \mathrm{~cm}^{-1} \mathrm{can}$ be expressed interaction between $\mathrm{OH}$ anthraquinone of madder on one hand and wool and mordant cationson the other hand was decreased free $\mathrm{OH}$ groups in wool.

\section{Determination of Flammability}

Table 1 shows the summary of the length, time and rate of burning for untreated and treated wool textiles. The images for untreated and treated wool fabrics after the flammability test (in both of acidic environment) are also given in Figures5and6. The longer burning length and higher burning rate indicated the greater the flammability. The untreated wool fiber ignites easily after exposing to flame. However from Table 1, it is clear that the burning length for sample dyeing with madderand $9 \%$ zirconium salt in acidic oxalic was decreased and

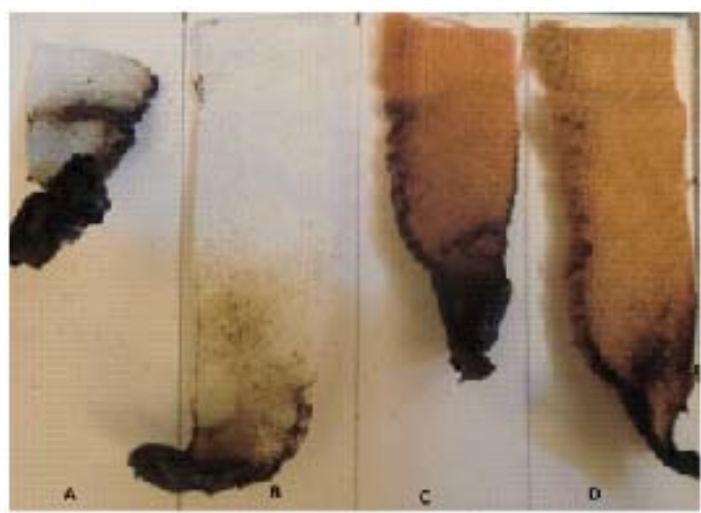

Fig. 5: Images of wool fabrics after the flammability test in acidic oxalic (A) untreated wool, (B) mordanted with $9 \%$ zirconium saltwool, (C) dyeing with madderwool (D) dyeing with madder and $9 \%$ zirconium salt wool the burning rate was significantly lower than that of untreated fabric; this decrement is also seen in sample mordanted with $9 \%$ zirconium salt. Also burning length and burning rate of sampledyeing with madder was decreased, it can be due to blocked sits of oxygen absorb by madder and hydrophobicity properties of samples.

It can be seen that the time needed for burning of the same length for dyeing with madderand $9 \%$ zirconium salt, mordanted with $9 \%$ zirconium salt and dyeing with maddersamples were longer compared with untreated wool.As can be seen in Table 1, also the burning length and burning rate for acid formic treated samples were decreased.

The wool is formed by fibrils, with helical coiled molecules, embedded in the amorphous matrix. The fibrils and the matrix consist of helical polypeptides chains interconnected by hydrogen, electrostatic and covalent linkages. The thermal properties and flammability of this natural polymer are influenced by its molecular structure, density, crystallization level, crystal orientation angle and mobility of molecular chains in amorphous and crystalline regions. Since mordanted of wool with zirconium salt and dyeing with madder cause some changes in chemical, physical and morphological characteristics of fiber thus changes in its flammability characteristics could also be expected.

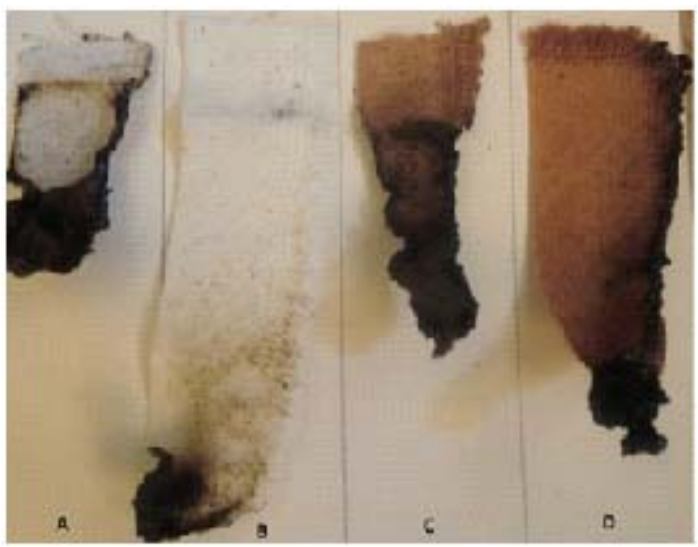

Fig. 6: Images of wool fabrics after the flammability test in acidic formic (A) untreated wool, (B) mordanted with $9 \%$ zirconium saltwool, (C) dyeing with madderwool (D) dyeing with madder and $9 \%$ zirconium salt wool 


\section{Microscopic Characterization}

The SEM images of untreated wool fiber and the samples treated with formic acid and oxalic acid and different concentrations of zirconium salt are shown in Figures7a-g (left and right). It can be observed that the dyeing with madder and formic acid mordanted fiber has scales of damaged more than samples of dyeing with madder and oxalic acid. The zirconia particles can be observed on the samples of oxalic acid treated due to the presence of most scales. It is evident that increment in zirconium salt concentration increased the aggregated particles on the surface of the fiber. By comparing the sample of formic acid in figure $(7 a$, right) with sample of oxalic acid in figure (7a, left) can be observed presence of particles which the tip of the scales is probably isolated by formic acid.
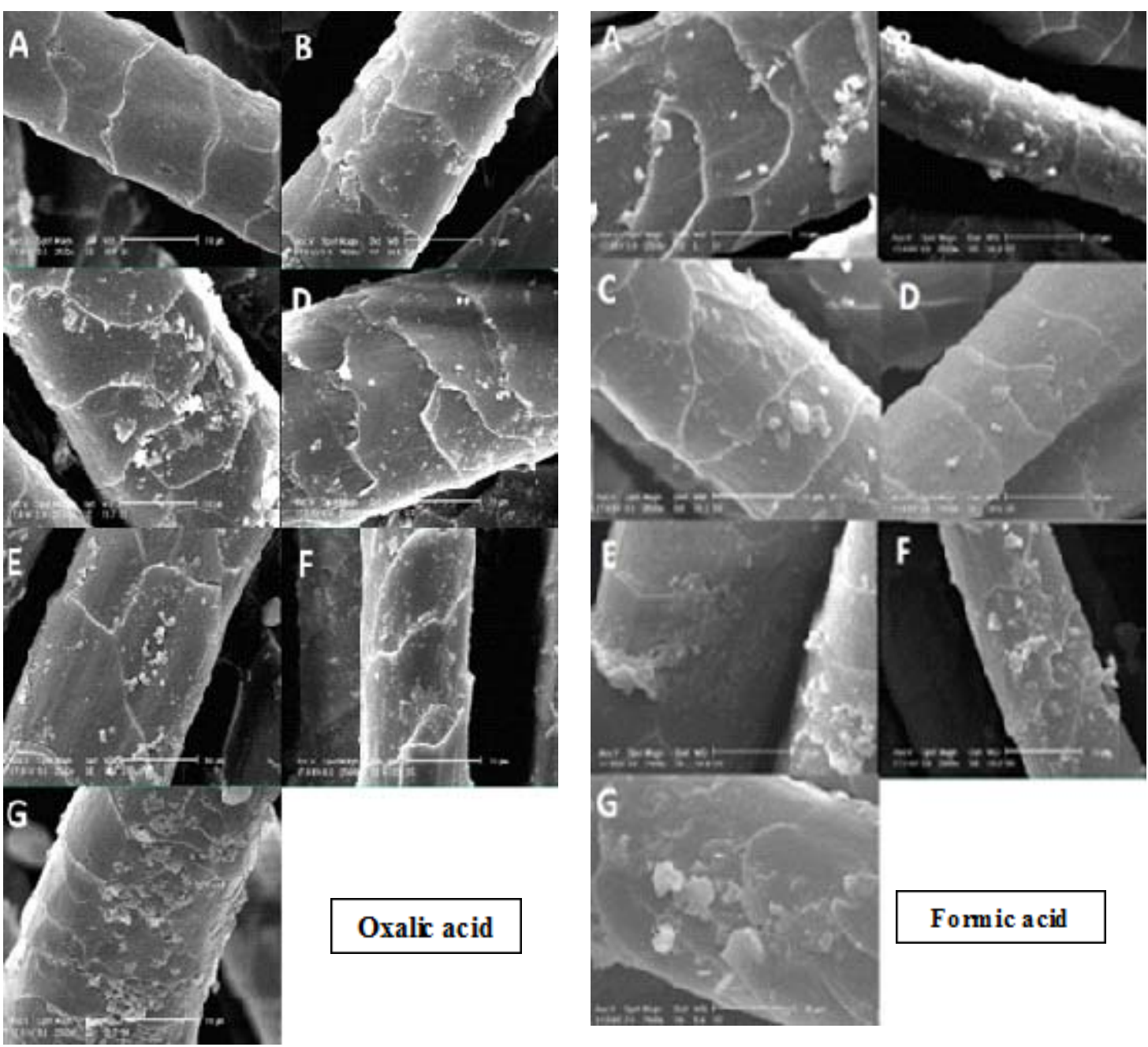

Fig. 7: SEM images in both of acidic environment (a) dyeing with madder wool fiber, (b) wool fibers dyeing with madder and $1 \%$ zirconium salt in before - mordant method (c) wool fibers dyeing with madder and $9 \%$ zirconium salt in before - mordant method (d) wool fibers dyeing with madder and $1 \%$ zirconium salt in simultaneously- mordant method (e) wool fibers dyeing with madder and $9 \%$ zirconium salt in simultaneously- mordant method

(f) wool fibers dyeing with madder and $1 \%$ zirconium salt in after-mordant method

(g) wool fibers dyeing with madder and $9 \%$ zirconium salt in after-mordant method 
Figures8a-g (left and right) and Table 2 show the presence of chemical elements on the surface of untreated fiber as well as on the surface of the wool dyeing with madder and zirconium salt as investigated by EDX analysis. In these patterns, $A u$ peaks clearly show that gold is successfully coated on surfaces of all fibers; and there is no $\mathrm{Zr}$ present on untreated wool. The EDX analysis of cross-linked wool illustrates more efficient interactions between the wool surface and zirconium salt leading to presence of $\mathrm{Zr}$ at this sample's surface. The surge of zirconium salt concentration increased presence of $\mathrm{Zr}$ and in aftermordant method is seen $\mathrm{Zr}$ more due to zirconium salt is an after-treatment method.

Several factors affect the ability of zirconium salt to aggregate on the surface of textiles including size, mobility, end-group functionalities, relative composition and molecular architecture. It seems that interactions between the wool and zirconium salt are strong enough to enable deposition of zirconium salt particles on the wool surface as a result of their wide surface area.
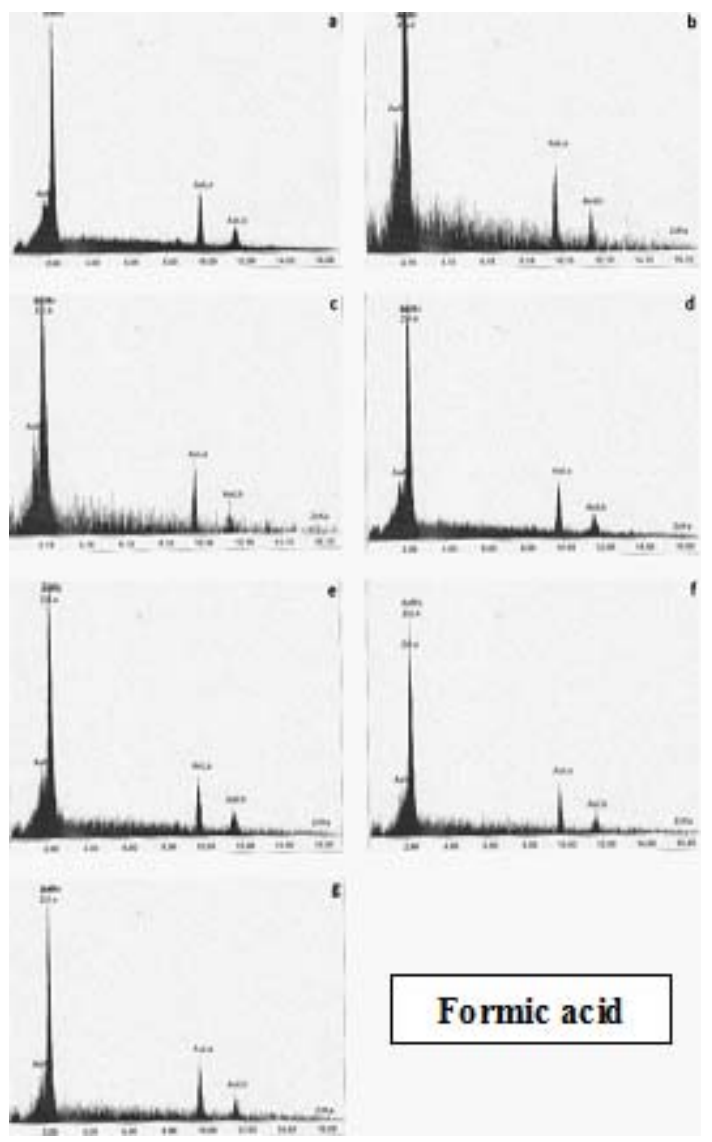
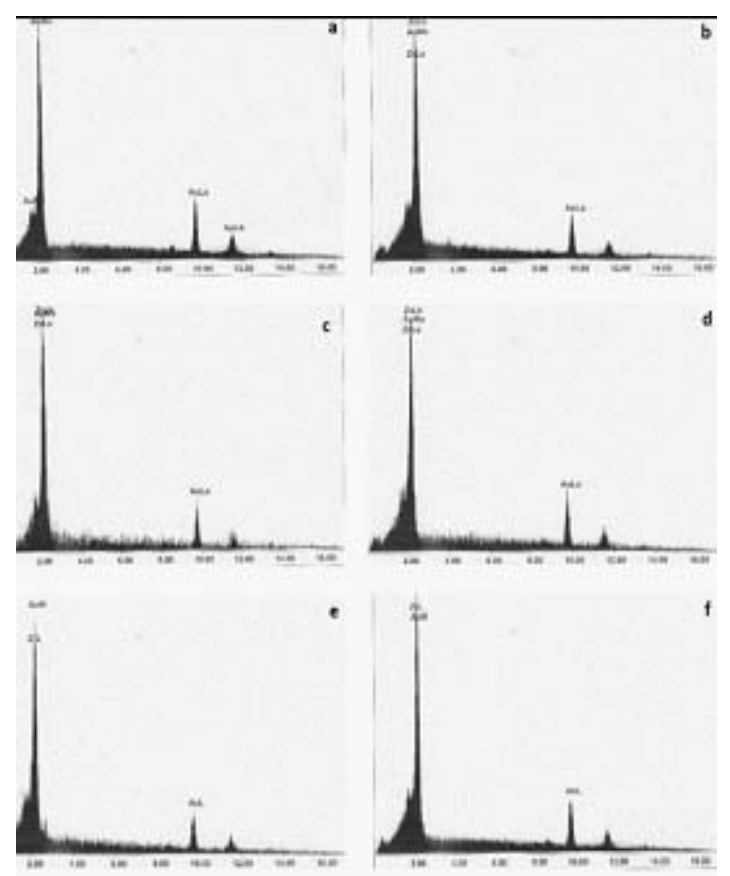

s

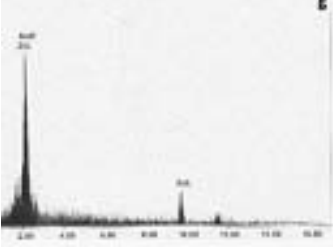

Oxalic acid

Fig. 8: Energy dispersive X-ray analysis inboth formic and oxalic acid environments (a) dyeing with madder wool fiber, (b) wool fibers dyeing with madder and $1 \%$ zirconium salt in beforemordantmethod (c) wool fibers dyeing with madder and $9 \%$ zirconium salt in beforemordantmethod (d) wool fibers dyeing with madder and $1 \%$ zirconium salt in simultaneouslymordantmethod (e) wool fibers dyeing with madder and $9 \%$ zirconium salt in simultaneouslymordantmethod (f) wool fibers dyeing with madder and $1 \%$ zirconium salt in after- mordantmethod (g) wool fibers dyeing with madder and $9 \%$ zirconium salt in after- mordant method 

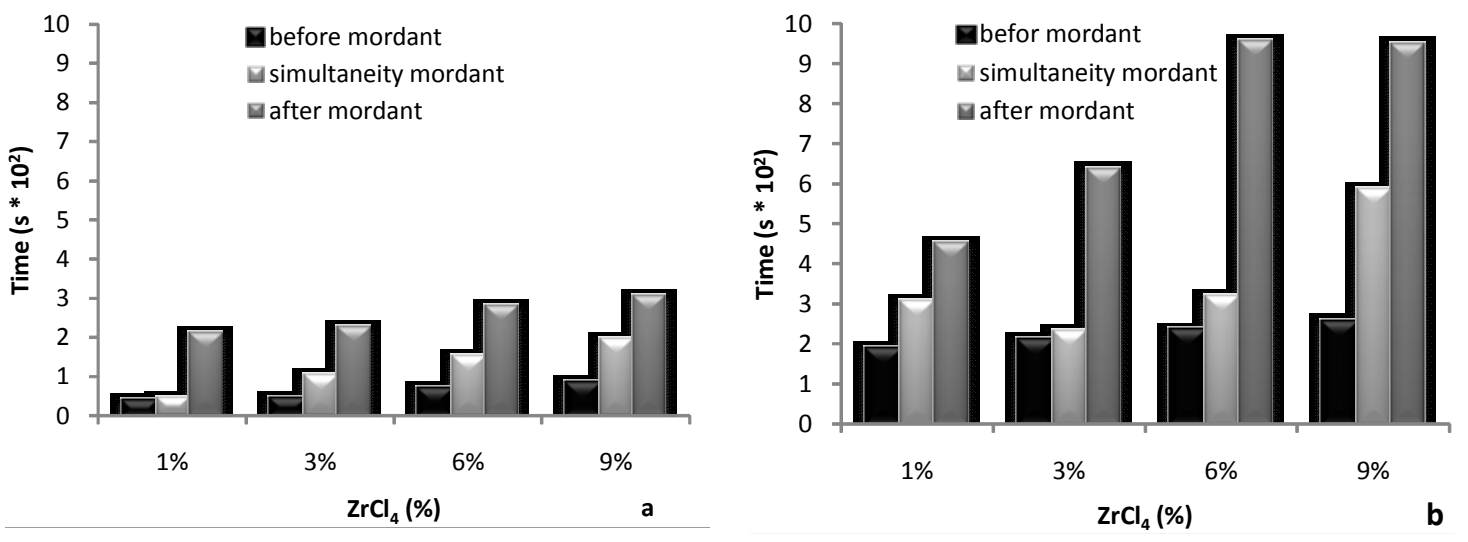

Fig. 9: Water droplet adsorption time on the dyeing with madder wool fabrics and different concentrations of zirconiumsalt ina) Oxalic acid, b) Formic acid
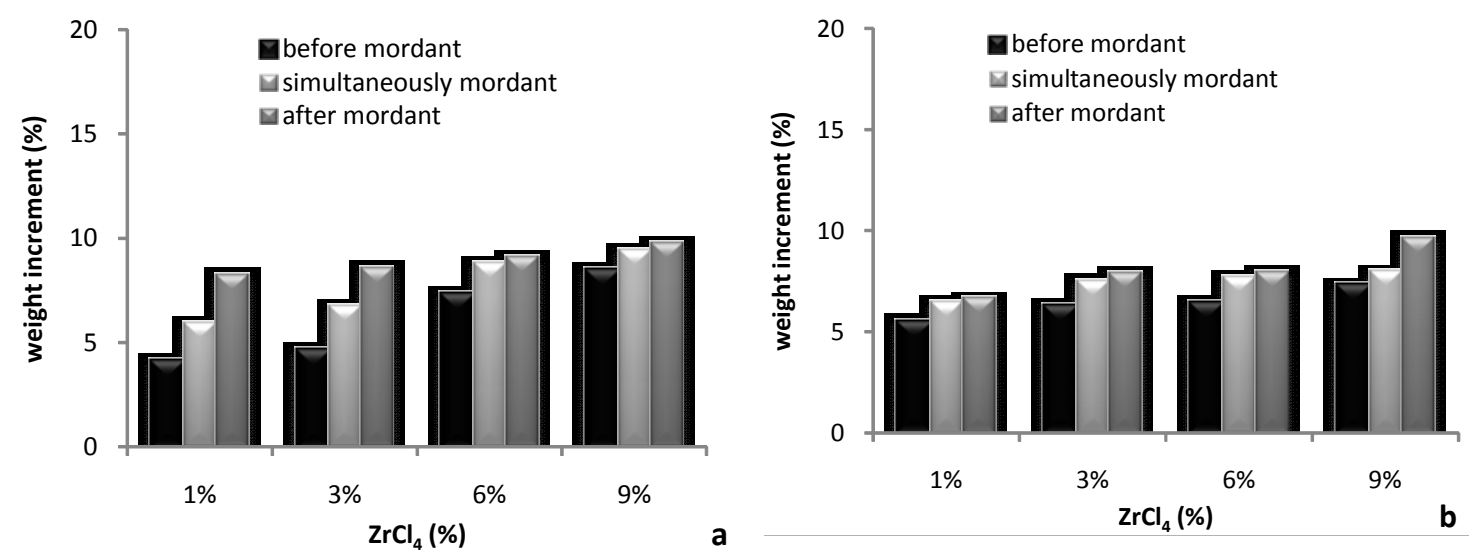

Fig. 10: Percent of increment weight of the dyeing with madder wool fabrics and different concentrations of zirconiumsalt ina) oxalic acid, b) formic acid
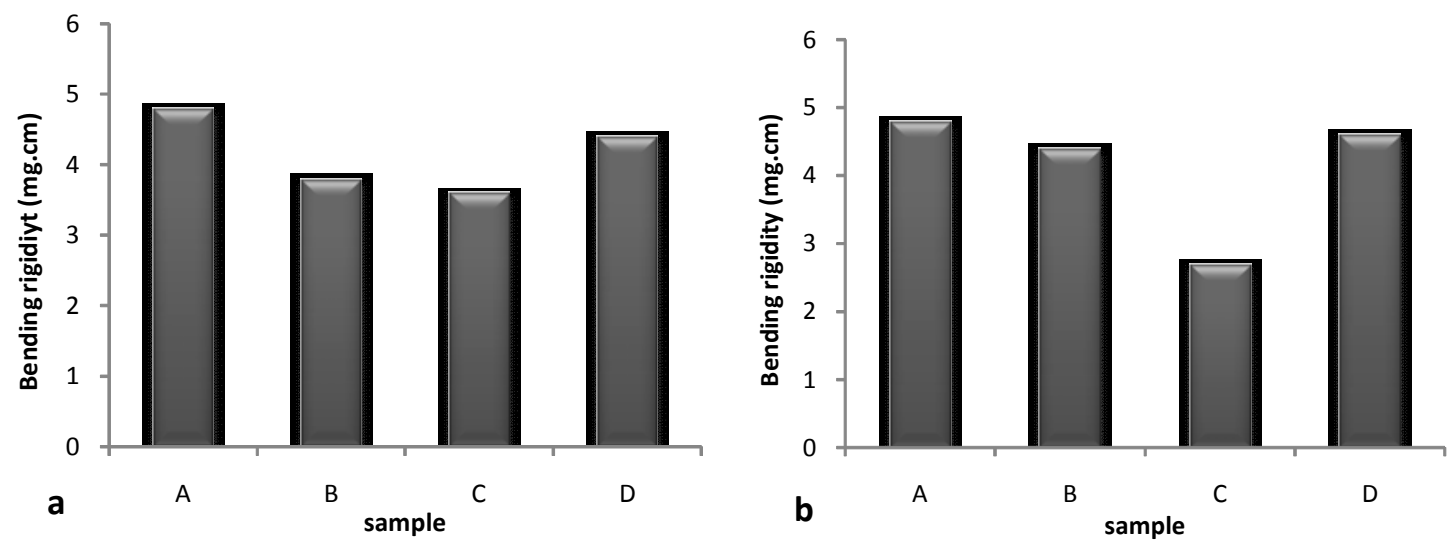

Fig 11: Bending rigidity ( $\mathrm{mg} . \mathrm{cm}$ ) in acidic oxalic (a) and acidic formic(b), (A) untreated wool, (B) mordanted with $9 \%$ zirconium saltwool, (C) dyeing with madderwool (D) dyeing with madder and $9 \%$ zirconium salt wool 


\section{Water Drop Adsorption Time}

Figure 9 shows the times measured for water droplets on dyeing with madder wool fabrics and different concentrations of zirconium salt. The adsorption and desorption of water from wool are related with the concentration and type of functional groups in protein chains. The results indicate that adsorption time increases with increment of concentration of zirconium salt. After-mordant method illustrates more adsorption time than two other methods, it seems that using zirconium salt as after-treatment caused to hydrophobicity.

Presence of ion zirconium and dyeing with madder caused to hydrophobicity properties, that in the SEM images have been confirm. Montazeret. al. reported hydrophobicity of Liposomes treated wool and dyeing with madder ${ }^{11}$.

\section{Determinationof Weightlncrement and Bending Rigidity}

Figure 10 shows the weight increment (in percentage) for samples treated with different zirconium salt concentrations of $1 \%, 3 \%, 6 \%$ and $9 \%$ (in both acidic environments). All zirconium salt concentrations increased weight of the wool and intensity of this increment has been more in aftermordant method than the other ones. Rise of weight increment of samples might be attributed to weight of ion $\mathrm{Zr}$ and forming of dye-salt-wool complex.

The bending rigidity of non-treated and zirconium salt treated wool samplesare illustrated in Figure 11. As can be seen, a $9 \%$ concentration of zirconium salt decreased the bending rigidity of fabric anddecreased thebending length. The zirconium salt in both acidsamples caused decrease in bending rigidity of samples hence improved thehandle of wool fabrics.

Drape is one of the important factors influencing the functionality and handle of textiles. It is defined as a phenomenon of fabric-fold formation, which arises when a fabric hangs downwithout the influence of external forces. The important influencing factors on the fabric'sdrapeability are its structure, yarn type, fiber content, shear, formability, fabric weight aswell as its finishing treatments. The greater the fabric weight, the better the drapeability.

\section{Colorimetric Measurements}

The color values were evaluated in CIELAB color space, the three axes being $L^{*}, a^{*}$, and $b^{*}$. The $L^{*}$ is the color coordinate which represents the lightness of samples and can be measured independently of thecolor hue. Any decrease in the lightness of samples could be concluded as the lower reflectance of textiles. The $a^{*}$ stands for the horizontal red-green color axis. The $b^{*}$ represents the vertical yellow-blue axis. The $C^{*}$ shows the brightness or dullness of the samples. Any increase in the $C^{*}$ of samples could be concluded as greater brightness of the composite. The hue angle $\left(h^{\circ}\right)$ stands for hue, which is the actual color recognized by the human eye and identified as orange, yellow, beige, brown, pink or any of the other colors visible to humans. It is expressed in degrees, with $0^{\circ}$ being a location on the $+a^{*}$ axis, continuing to $90^{\circ}$ for the $+b^{*}$ axis, $180^{\circ}$ for $-a^{*}, 270^{\circ}$ for $-b^{\star}$, and back to $360^{\circ}=0^{\circ}$.

The $L^{*}, a^{*}, b^{*}, C^{*}$ and $h$ values of zirconium saltmordanted madder dyed wool fabrics and unmordanted, are given in Tables3and4.As can be seen in Table 3,the lightness $\left(L^{*}\right)$ values decreasedin beforeandsimultaneously-mordant method and in after-mordant method were not significant. Decrease in $L^{*}$ values could be the results of more dyes penetration into the zirconium saltmordantedwool fabrics which allows the results of exhaustion values. There existeda change in $a^{*}$, $b^{*}, C^{*}$ and $h$ for zirconium saltmordantedmadder dyed wool fabrics, and an increment of yellow is seen in after-mordant method.

Also can be seen in Table 4, the lightness $\left(L^{*}\right)$ values increasedin beforeandsimultaneouslymordant method, could be the results of less dyes penetration into the zirconium saltmordantedwool fabrics; and in after-mordant method was not significant. There was achangein $a^{*}, b^{*}, C^{*}$ and $h$ for zirconium saltmordantedmadder dyed wool fabrics, and also can be seen yellow of samples increase in beforeandsimultaneously-mordant method.Less dyes penetration into wool fabrics could be due to interaction between $\mathrm{OH}$ anthraquinone of madder on one hand and wool and mordant cations on the other hand, caused decrement of free $\mathrm{OH}$ groups in wool. This result is 
incidentally consistent with our results obtained fromthe FTIR spectra.

The results obtained from color coordinates of samples indicated that mordant content, mordanting method and type of acid caused change in color shade.

\section{CONCLUSION}

Zirconium salt and madder was used for dyeing of wool through before, simultaneously and after-mordantingmethods. The FTIR spectra showed that zirconium salt increased the interfacial interactions and bonding with the amine or hydroxyl end groups of wool chains by interactions and conformation changes. The results obtained from the LOI test demonstrated a decrement of flammability of mordanted samples. This can be as a result of the heat insulation effect of zirconium salt particles embedded in fibers. The hydrophobic propertiesincreased in mordanting samples that can be attributed to the dyeing with madder and presence of zirconium salt.

\section{REFERENCES}

1. Bearpark F,The Dyeing And Finishing of Wool Fabrics, William Marriott And J. Park, 1996,. $43-50$

2. Simpson W.S., CrawshawG.H., Wool: Science And Technology, 2002,.60-70

3. FarizadehK.,Yazdanshenas M.E.,Montazer M.,Malek R.M.A. , RashidiA., Kinetic Studies of Adsorption of Madder on Wool Using Various Models, Text Res J, 2010,. 80,.847855

4. Banyai, P., Kuzovklina, I.N., Kursinszki, L., and Szoke, E., HPLC analysis of alizarin and purpurin produced by Rubiatinctorum L. hairy root cultures, Chromatographia Supplement, 2006., 63, 66-72

5. Derksen, G. C. H., Naayer, M., Beek, T. A. V., Capelle, A., Haaksman, I. K., Doren, H. A.V., and Groot, E. D., Chemical and enzymatic hydrolysis of anthraquinone glycosides from madder roots, Phytochem. Anal. 2003.,14, 137-144

6. Derksen, G. C. H., Lelyveld, G. P., Beek, T. A.
V., Capelle, A., and Groot, E. D., To Validated HPLC methods for the quantification of alizarin and other anthraquinones in Rubiatinctorum cultivars, Phytochem. Anal., 2004.,15, 397-406

7. ParvinzadehM., EslamiS.,Optical and electromagnetic characteristics of clay-iron oxide nanocompositesRes. Chem. Intermed. 2011,.73 771-784

8. Cho, L.L., Forensic Sci. J. 2007,.6,. 55-62.

9. ParvinzadehM., AssefipourR., KiumarsiA., Biohydrolysis of nylon 6,6 fiber with different proteolytic enzymes, Polym. Degrad. Stabil. 2009.,94., 1197-1205

10. ParvinzadehM.,Effect of proteolytic enzyme on dyeing of wool with madder,Enzym. Microb.Technol 2007,. 40 .17-19

11. MontazerM., TaghaviF. A., ToliyatT., BameniMoghadamM., Optimization of Dyeing of Wool with Madder and Liposomes by Central Composite Design, J AppIPolymSci, 2007.,106.,1614-1621. 